\title{
PENGARUH MODEL PEMBELAJARAN BERBASIS MASALAH TERHADAP HASIL BELAJAR SISWA PADA MATERI POKOK BESARAN FISIKA DAN SATUANNYA
}

\author{
Henok Siagian dan Hunter Lumbanbatu \\ hunter_lumbanbatu@yahoo.co.id \\ Jurusan Fisika FMIPA Universitas Negeri Medan \\ Jalan Willem Iskandar Pasar V Medan, 20221
}

\begin{abstract}
This research aimed to determine the effect of Problem Based Learning Model on physics learning outcome of students in the subject physics mulberry and its unit in X class SMA Katolik Budi Murni 3 of Medan T.P 2013/2014. The kinds of this reaserch is quasi-experimental. The population in this research is all of the students of X class SMA Katolik Budi Murni 3 of Medan which consisting of 4 classes totally 130 sample students . the cluster random sampling was done by taking 2 classes of 4 classes are randomly. The class of X-2 as experiment class and X-4 as control class that each class is 34 and 36 students. The instrument used achievement test is a multiple-choice test consist of 10 questions that have fulfilled content validity. The eksperimental class treated by using Problem Based Learning Model and control class by using convensional model. Based on t test that $\mathrm{Ha}$ is accepted, it means that Problem Based Learning Model has significant impact in improving student learning outcomes.
\end{abstract}

Keywords : Problem Based Learning Model, Studing Result and Student Activity.

PENDAHULUAN

Pendidikan

investasi sumber dalam jangka panjang yang mempunyai nilai strategis bagi kelangsungan peradaban manusia di dunia. Tingginya kualitas sumber daya manusia akan membawa kemajuan suatu bangsa. Berbagai carapun dilakukan untuk memenuhi sistem pendidikan di Indonesia baik secara pendidikan formal maupun pendidikan informal.

Berkembangnya pendidikan juga akan mempengaruhi perkembangan Ilmu Pengetahuan dan Teknnologi (IPTEK). Fisika sebagai salah satu ilmu pengetahuan alam memiliki sumbangan yang besar terhadap kemajuan IPTEK dengan berbagai penemuan di bidang sains dan teknologi. Fisika sebagai cabang Ilmu Pengetahuan Alam (IPA) mempelajari gejala-gejala alam dan interaksi di dalamnya.

Selama ini para siswa berpendapat bahwa pelajaran fisika merupakan pelajaran yang sulit karena mereka lebih banyak menemui persamaan matematis sehingga fisika diidentikkan dengan angka dan rumus. Pembelajaran fisika hanya memfokuskkan 
persamaan-persamaan fisika dan mengutamakan perhitungan daripada menjelaskan konsep, hubungan fisika di dalam kehidupan sehari-hari dan masalahmasalah fisika di dalam kehidupan sehari-hari. Akibatnya, siswa menganggap pelajaran fisika merupakan pelajaran yang tidak menarik. Hal ini berdampak pada rendahnya minat siswa untuk belajar fisika. Masalah ini merupakan masalah yang sering dijumpai oleh para guru di sekolah. Berdasarkan hasil angket yagn disebar oleh peneliti kepada 34 siswa pada Juli 2014 di SMA Katolik Budi Murni 3 Medan diperoleh data bahwa $32 \%$ siswa tidak menyukai pelajaran fisika, $56 \%$ siswa biasa-biasa saja terhadap mata pelajaran fisika, $29 \%$ siswa menyukai pelajaran fisika. Siswa yang tidak menyukai fisika tentunya tidak akan termotivasi untuk mempelajari fisika.

Berdasarkan hasil observasi yang dilakukan peneliti, ternyata guru fisika di sekolah tersebut tidak menggunakan model pembelajaran yang bervariasi selama proses pembelajaran fisika. Guru fisika hanya menggunakan model pembelajaran konvensional yang berupa kegiatan ceramah, tanya jawab, mencatat dan mengerjakan soal. Guru lebih banyak menggunakan metode ceramah dalam proses pembelajaran fisika. Siswa kurang terlibat aktif dalam pembelajaran karena hanya menjadi pendengar, pembelajaran fisika masih bersifat teacher center. Pembelajaran fisika juga hanya berorientasi pada hapalan dan rumus tanpa memahami konsep dari fisika tersebut. Pelajaran fisika bukanlah mata pelajaran yang hanya menuntut kemampuan menghapal rumus-rumus yang diberikan, tetapi juga harus terampil dalam mengaplikasikannya untuk menyelesaikan masalah fisika di dalam kehidupan sehari-hari. Hal ini ditekankan untuk meningkatkan kompetensi berpikir kritis dan sistem dalm memahami konsep fisika, sehingga siswa memperoleh pemahaman yang benar tentang fisika.

Masalah-masalah di atas menyebabkan hasil belajar fisika siswa rendah. Hal ini sesuai dengan hasil wawancara peneliti dengan guru fisika di sekolah tersebut yang menyatakan bahwa hasil belajar fisika siwa kelas X masih rendah jika dilihat dari nilai Kriteria Ketuntasan Minimal (KKM) yaitu 65. Pada T.P. 2011/2012 nilai rataratanya 62 dan pada T.P. 2012/2013 nilai rata-ratanya 64 . Data ini menunjukkan bahwa nilai rata-rata ujian fisika kelas X SMA Budi Murni 3 Medan untuk tahun kedua Tahun Pelajaran tersebut masih tergolong rendah.

Berdasarkan masalah di atas, perlu dilakukan pembenahan dalam mengatasi pembelajaran teacher centered. Penulis ingin mencoba menerapkan model pembelajaran berbasis masalah sebagai salah satu alternatif untuk memecahkan masalah-masalah di atas dalam upaya meningkatkan hasil belajar siswa.

Model pembelajaran berbasis
masalah merupakan model pembelajaran dimana siswa belajar melalui pemecahan masalah dan merefleksikan pengalaman mereka. Dengan menggunakan model ini maka siswa dapat berperan aktif dalam memecahkan masalah dalam 
proses pembelajaran khususnya pada materi fisika serta mampu memahami konsep (prinsip yang abstrak), mampu bersikap kritis, siswa dapat mengembangkan sifat ilmiah di dalam dirinya dan mampu bertanggung jawab menyelesaikan masalah, baik masalah individu maupun masalah dalam kelompok, dimana siswa akan dituntun untuk bekerjasama dengan siswa yang lain.

Penelitian mengenai model pembelajaran berbasis masalah sudah pernah diteliti oleh Kennedy (2009) dan L. Siagian (2010), hasil pene;itian tersebut menunjukkan ada peningkatan hasil belajar siswa tetapi masih terdapat kelemahankelemahan, antara lain teknik pengelompokan yang dilakukan berdasarkan absensi sehingga dapat memungkinkan dalam kelompok hanya terdiri dari siswa yang berkemampuan rendah dan kemampuan tinggi dalam sehingga kelompok yang berkemampuan rendah jauh ketinggalan dari pada kelompok lainnya dan dapat memungkinkan siswa jadi malas belajar.(2) Penyampaian materi pelajaran oleh kelompok ahli masih canggung mereka masih bergantung pada catatan dan kurang rasa percaya diri karena mereka beranggapan belum mampu untuk menyampaikan materi pelajaran.

Berdasarkan latar belakang masalah di atas peneliti tertarik untuk melakukan penelitian dengan judul : Pengaruh Model Pembelajaran Berbasis Masalah Terhadap Hasil Belajar Siswa Pada Materi Pokok Besaran Fisika dan Satuannya di Kelas X Sememster I SMA Katolik Budi Murni 3 Medan.

Adapun yang menjadi tujuan penelitian ini adalah untuk mengetahui pengaruh model pembelajaran berbasis masalah terhadap hasil belajar siswa pada materi pokok besaran dann satuannya di kelas X SMA Katolik Budi Murni 3 Medan.

\section{METODE PENELITAN}

Penelitian ini dilaksanakan di SMA Katolik Budi Murni 3 Medan dengan populasi seluruh siswa kelas X SMA Katolik Budi Murni 3 Medan yang berjumlah 130 siswa yang terdiri dari 4 kelas. Teknik pengambilan sampel dilakukan dengan cara teknik sampel kelas acak (cluster random sampling). Sampel kelas dimabil dari populasi sebanyak 2 kelas X-2 dengan menggunakan model pembelajaran berbasis masalah dan kelas X-4 sengan menggunakan model konvensional. Untuk mengetahui hasil belajar siswa dilakukan dengan memberikan tes pada kedua kelas sesbelum dan sesudah diberi perlakuan. Rancangan penelitian quasi eksperimen ini dengan desain pretes dan postes. Rancangan penelitian ini ditunjukkan pada Tabel 1.

Tabel 1. Rancangan Penelitian

\begin{tabular}{|c|c|c|c|}
\hline Kelas & Pretes & $\begin{array}{c}\text { Perlakuan } \\
\text { (Variabel bebas) }\end{array}$ & $\begin{array}{c}\text { Poste } \\
\mathbf{s}\end{array}$ \\
\hline Eksperimen & $\mathrm{T}_{1}$ & $\mathrm{X}_{1}$ & $\mathrm{~T}_{2}$ \\
\hline Kontrol & $\mathrm{T}_{1}$ & $\mathrm{X}_{2}$ & $\mathrm{~T}_{2}$ \\
\hline
\end{tabular}

$\mathrm{T}_{1}$ : Tes kemampuan awal (pretes) untuk kelas eksperimen dan kelas kontrol.

$\mathrm{T}_{2}$ : Tes kemampuan akhir (postes) untuk kelas eksperimen dan kelas kontrol.

$\mathrm{X}_{1}$ : Perlakuan pembelajaran dengan model pembelajaran berbasis masalah.

$\mathrm{X}_{2}$ : Perlakuan pembelajaran konvensional. 
Instrumen penelitian yang digunakan untuk mengumpulkan data hasil belajar siswa digunakan tes hasil belajar ini terdiri dari 10 soal pilihan berganda yang ranah kognitifnya dimulai dari $\mathrm{C}_{3}, \mathrm{C}_{4}, \mathrm{C}_{5}$ dan $\mathrm{C}_{6}$. Tes hasil belajar ini digunakan untuk mengetahui kemampuan siswa pada tingkat kognitif. Perincian kisi-kisi tes hasil belajar siswa ditunjukkan pada Tabel 2.

Tabel 2. Perincian Kisi-Kisi Tes Hasil Belajar Siswa

\begin{tabular}{|c|c|c|c|c|c|c|c|c|}
\hline \multirow{2}{*}{$\begin{array}{l}\mathrm{N} \\
\mathrm{O}\end{array}$} & \multirow{2}{*}{$\begin{array}{c}\text { Materi } \\
\text { pokok }\end{array}$} & \multicolumn{6}{|c|}{ Ranah kognitif } & \multirow{2}{*}{$\underset{\mathrm{h}}{\text { Jumla }}$} \\
\hline & & $\begin{array}{l}\mathrm{C} \\
1\end{array}$ & $\begin{array}{l}\mathrm{C} \\
2\end{array}$ & $\begin{array}{l}\mathrm{C} \\
3\end{array}$ & $\begin{array}{l}\mathrm{C} \\
4\end{array}$ & $\begin{array}{l}\mathrm{C} \\
5\end{array}$ & $\begin{array}{l}\mathrm{C} \\
6\end{array}$ & \\
\hline 1 & $\begin{array}{c}\text { Besara } \\
\text { n dan } \\
\text { Satuan }\end{array}$ & & & 2 & $\begin{array}{l}1, \\
3\end{array}$ & & & 3 \\
\hline 2 & $\begin{array}{l}\text { Peng } \\
\text { ukura } \\
\text { n }\end{array}$ & & & 4 & & $\begin{array}{l}5, \\
7\end{array}$ & 6 & 4 \\
\hline 3 & $\begin{array}{l}\text { Pengg } \\
\text { unaan } \\
\text { Angka } \\
\text { Pentin } \\
\text { g }\end{array}$ & & & $\begin{array}{c}8, \\
9\end{array}$ & & & $\begin{array}{l}1 \\
0\end{array}$ & 3 \\
\hline \multicolumn{2}{|c|}{ Jumlah } & & & 4 & 2 & 2 & 2 & 10 \\
\hline
\end{tabular}

Uji hipotesis yang digunakan dengan menggunakan uji t dengan membandingkan rata-rata skor hasil belajar yang dicapai baik kelas eksperimen maupun kelas kontrol. Data yang diperoleh ditabulasikan kemudian dicari rata-ratanya. Sebelum dilakukan penganalisisan data, terlebih dahulu ditentukan skor masing-masing kelompok sampel lalu dilakukan pengolahan data dengan langkah-langkah sebagai berikut: menghitung nilai rata-rata dan simpangan baku, uji normalitas, uji homogenitas, uji kesamaan rata-rata pretes, pengujian hipotesis. (Sudjana, 2005) Sintaks model pembelajaran berbasis masalah diadopsi dari (Trianto 2007) seperti ditunjukkan pada Tabel 3 berikut:

Tabel 3. Sintaks model pemebelajaran berbasis masalah

\begin{tabular}{|c|c|}
\hline Fase & Aktivitas guru \\
\hline $\begin{array}{l}\text { Fase-1 } \\
\text { Pengajuan } \\
\text { Masalah. }\end{array}$ & $\begin{array}{l}\text { Guru menjelaskan } \\
\text { tujuan pembelajaran, } \\
\text { menjelaskan logistik } \\
\text { yang dibutuhkan, } \\
\text { memotivasi siswa agar } \\
\text { terlibat pada aktivitas } \\
\text { pemecahan masalah } \\
\text { yang dipilihnya. }\end{array}$ \\
\hline $\begin{array}{l}\text { Fase-2 } \\
\text { Mengorganisasi } \\
\text { siswa untuk } \\
\text { belajar. }\end{array}$ & $\begin{array}{l}\text { Guru membantu siswa } \\
\text { mendefinisikan dan } \\
\text { mengorganisasikan } \\
\text { tugas belajar yang } \\
\text { berhubungan dengan } \\
\text { masalah tersebut. }\end{array}$ \\
\hline $\begin{array}{l}\text { Fase-3 } \\
\text { Penyelidikan } \\
\text { Otentik. }\end{array}$ & $\begin{array}{l}\text { Guru mendorong siswa } \\
\text { untuk mengumpulkan } \\
\text { informasi yang sesuai, } \\
\text { melaksanakan } \\
\text { eksperimen untuk } \\
\text { mendapatkan penjelasan } \\
\text { dan pemecahan } \\
\text { masalah. }\end{array}$ \\
\hline $\begin{array}{l}\text { Fase-4 } \\
\text { Menghasilkan } \\
\text { produk/karya dan } \\
\text { menyajikannya. }\end{array}$ & $\begin{array}{l}\text { Guru membantu siswa } \\
\text { dalam merencanakan } \\
\text { dan menyisipkan karya } \\
\text { sesuai seperti laporan, } \\
\text { video, dan model serta } \\
\text { membantu mereka } \\
\text { untuk berbagi tugas } \\
\text { dengan temannya }\end{array}$ \\
\hline $\begin{array}{l}\text { Fase-5 } \\
\text { Menganalisis dan } \\
\text { mengevaluasi } \\
\text { proses pemecahan } \\
\text { masalah. }\end{array}$ & \begin{tabular}{lr} 
Guru menbantu siswa \\
untuk & \multicolumn{2}{c}{ melakukan } \\
refleksi atau evaluasi \\
terhadap penyelidikan \\
mereka dan proses- \\
proses yang meraka \\
gunakan
\end{tabular} \\
\hline
\end{tabular}

Uji hipotesis menggunakan uji t dua pihak dengan syarat data berdistribusi normal dan homogen. Hipotesis yang diuji berbentuk: 
$\begin{array}{rlr}\mathrm{H}_{\mathrm{o}}: \mu_{1}=\mu_{2} & \text { kelas eksperimen dan } \\ & \text { kelas } \\ & \text { mempunyai } \\ & \text { kemampuan awal } \\ & \text { sama } \\ \mathrm{H}_{\mathrm{a}}: \mu_{1} \neq \mu_{2}: & \text { kelas eksperimen dan } \\ & \text { kelas } \\ & \text { mempunyai kontrol } \\ & \text { kemampuan awal } \\ & \text { berbeda }\end{array}$

Uji hipotesis menggunakan uji t satu pihak dengan syarat data berdistribusi normal dan homogen. Hipotesis yang akan diuji adalah : $\mathrm{Ha}: \mu_{1}>\mu_{2}:$ Hasil belajar fisika dengan model pembelajaran berbasis masalah lebih baik daripada model pembelajaran

konvensional pada materi pokok besaran fisika dan satuannya.

Kriteria pengujian yang berlaku ialah : $\mathrm{H}_{\mathrm{o}}$ jika $\mathrm{t}<\mathrm{t}_{1-\alpha}$, dimana $t_{1-a}$ di dapat dari daftar distribusi $\mathrm{t}$ dengan $\mathrm{dk}=\left(\mathrm{n}_{1}+\mathrm{n}_{2}-2\right)$ dan peluang $\left(t_{1-\alpha}\right)$ dan $\alpha=0,05$. Jika $\mathrm{t}$ mempunyai harga-harga lain $\mathrm{H}_{\mathrm{o}}$ di tolak. (Sudjana, 2005).

Untuk menguji apakah populasi berdistribusi normal atau tidak, dapat dilakukan uji normalitas. Langkah awal yang dilakukan adalah menentukan nilai rata-rata sebelum dilakukan uji normalitas.

Untuk menentukan nilai rata-rata digunakan rumus (Sudjana, 2005:67), yaitu:

$$
\bar{X}=\frac{\sum X_{i}}{n}
$$

Untuk

menghitung simpangan baku (s) digunakan rumus (Sudjana, 2005:94), yaitu:

$$
s=\sqrt{\frac{n \sum x_{i}{ }^{2}-\left(x_{i}\right)^{2}}{n(n-1)}}
$$

Setelah menentukan nilai rata-rata dan simpangan baku lalu dilakukan uji liliefors.

\section{HASIL DAN PEMBAHASAN}

\section{a. Hasil Penelitian}

Hasil penelitian ini adalah bahwa nilai rata-rata pretes kelas eksperimen sebesar 4,29 dan nilai rata-rata pretes kelas kontrol sebesar 4,03. Data nilai pretes kelas eksperimen dan kelas kontrol ditunjukkan pada Tabel 4 .

Tabel 4. Data Nilai Pretes Kelas

\begin{tabular}{|c|c|c|c|c|c|}
\hline \multicolumn{3}{|c|}{ Kelas Eksperimen } & \multicolumn{3}{|c|}{ Kelas Kontrol } \\
\hline $\begin{array}{l}\text { Nila } \\
\text { i }\end{array}$ & $\begin{array}{c}\text { Frekuen } \\
\text { si }\end{array}$ & $\begin{array}{c}\text { Rat } \\
\mathrm{a}^{-} \\
\text {rata }\end{array}$ & $\begin{array}{l}\text { Nila } \\
\text { i }\end{array}$ & $\begin{array}{c}\text { Frekuen } \\
\text { si }\end{array}$ & $\begin{array}{c}\text { Rat } \\
\mathrm{a}^{-} \\
\text {rata }\end{array}$ \\
\hline 2 & 3 & \multirow{7}{*}{4,29} & 1 & 1 & \multirow{7}{*}{4,03} \\
\hline 3 & 7 & & 2 & 5 & \\
\hline 4 & 9 & & 3 & 8 & \\
\hline 5 & 8 & & 4 & 8 & \\
\hline 6 & 6 & & 5 & 7 & \\
\hline \multirow[t]{2}{*}{7} & 1 & & 6 & 6 & \\
\hline & & & 7 & 1 & \\
\hline \multicolumn{2}{|c|}{$\mathrm{n}=34$} & & \multicolumn{2}{|c|}{$\mathrm{n}=36$} & \\
\hline
\end{tabular}
Eksperimen dan Kelas Kontrol

Berdasarkan Tabel 4 dapat dilihat bahwa lima belas orang siswa yang dapat dinyatakan tuntas pada kelas eksperimen dan sebelas orang pada kelas kontrol. Hal ini terjadi memang siswa tersebut serius dan tenang saat mengerjakan soal. Mereka hanya terfokus pada soal dan tidak terpengaruh dengan temannya yang ribut. Sementara siswa-siswa yang tidak tuntas kurang serius ketika mengerjakan soal yang diberikan peneliti. Sebagian dari mereka sibuk dengan telepon genggam, sebagian ada yang sepele sementara yang lainnya ribut 
dan tidak mau tahu. Tentunya, hal ini dapat mempengaruhi hasil nilai postes mereka.

Setelah diberikan perlakuan yang berbeda dimana pada kelas eksperimen diberikan model pemebelajaran berbasis masalah dan model pembelajaran konvensional pada kelas kontrol diperoleh rata-rata postes kelas eksperimen 6,29 dan rata-rata postes kelas kontrol 5,64. Data nilai postes kelas eksperimen dan kelas kontrol ditunjukkan pada Tabel 5.

Tabel 5. Data nilai postes kelas eksperimen dan kelas kontrol

\begin{tabular}{|c|c|c|c|c|c|}
\hline \multicolumn{3}{|c|}{ Kelas Eksperimen } & \multicolumn{3}{|c|}{ Kelas Kontrol } \\
\hline $\begin{array}{c}\text { Nila } \\
\text { i }\end{array}$ & $\begin{array}{c}\text { Frekuen } \\
\text { si }\end{array}$ & $\begin{array}{c}\text { Rata- } \\
\text { rata }\end{array}$ & $\begin{array}{c}\text { Nila } \\
\text { i }\end{array}$ & $\begin{array}{c}\text { Frekuen } \\
\text { si }\end{array}$ & $\begin{array}{c}\text { Rata- } \\
\text { rata }\end{array}$ \\
\hline 3 & 1 & \multirow{8}{*}{6,29} & 3 & 3 & \multirow{8}{*}{5,64} \\
\hline 4 & 5 & & 4 & 7 & \\
\hline 5 & 3 & & 5 & 7 & \\
\hline 6 & 10 & & 6 & 8 & \\
\hline 7 & 7 & & 7 & 6 & \\
\hline 8 & 5 & & 8 & 4 & \\
\hline 9 & 3 & & 9 & 1 & \\
\hline \multicolumn{2}{|c|}{$\mathrm{n}=34$} & & \multicolumn{2}{|c|}{$\mathrm{n}=36$} & \\
\hline
\end{tabular}

Berdasarkan data pada Tabel 5 dapat dilihat bahwa nilai postes kelas eksperimen lebih tinggi dibandingkan dengan kelas kontrol sehingga dapat dikatakan bahwa model pembelajaran berbasis masalah memberikan pengaruh yang signifikan terhadap hasil belajar siswa pada materi pokok besaran fisika dan satuannya di kelas X semester I SMA Katolik Budi Murni 3 Medan T.P. 2013/2014.

Hasil peneliti ini menunjukkan bahwa siswa yang tuntas sebesar $44,00 \%$ dan secara kelas dinyatakan tidak tuntas (jumlah siswa yang tuntas tidak mencapai 85 \%). Sedangkan Hasil belajar siswa dengan menggunakan model pembelajaran konvensional secara individu siswa yang tuntas sebesar $31 \%$ dan secara kelas dinyatakan tidak tuntas (jumlah siswa yang tuntas tidak mencapai $85 \%)$. Hasil belajar ini dipengaruhi oleh tingkah laku para siswa ketika ujian sedang berlangsung. Siswa yang dinyatakan tuntas tersebut memang terlihat serius dan tenang saat mengerjakan soal saat ujian berlangsung. Mereka hanya terfokus pada soal dan tidak terpengaruh dengan temannya yang ribut. Sementara siswa-siswa yang tidak tuntas kurang serius ketika mengerjakan soal yang diberikan peneliti. Sebagian dari mereka sibuk dengan telepon genggam mereka masing-masing, sebagian ada yang sepele sementara yang lainnya ribut, tidak mau tahu dan sebagian lagi ada yang sering pindah-pindah tempat duduk saat ujian sedang berlangsung. Tentunya, hal ini berdampak pada hasil nilai postes mereka.

Perhitungan uji perbedaan nilai rata-rata postes kelas eksperimen dan kelas kontrol, diperoleh $t_{\text {hitung }}=1,714>t_{\text {tabel }}=$ 1,668, maka $\mathrm{H}_{0}$ ditolak, sehingga diperoleh kesimpulan bahwa ada pengaruh model pembelajaran berbasis masalah terhadap hasil belajar siswa pada materi pokok besaran fisika dan satuannya di kelas X SMA Katolik Budi Murni 3 Medan T.P. 2013/2014. Ringkasan Perhitungan Uji Hipotesis Kemampuan Postes ditunjukkan pada Tabel 6. 
Tabel 6. Ringkasan Perhitungan Uji Hipotesis Kemampuan Postes

\begin{tabular}{|c|c|c|c|c|c|}
\hline $\begin{array}{c}\mathbf{N} \\
\mathbf{o}\end{array}$ & $\begin{array}{c}\text { Data } \\
\text { Kelas }\end{array}$ & $\begin{array}{c}\text { Nillai } \\
\text { Rata- } \\
\text { Rata }\end{array}$ & $\begin{array}{c}\mathrm{t}_{\text {hitun }} \\
\mathrm{g}\end{array}$ & $\mathrm{t}_{\text {tabel }}$ & $\begin{array}{c}\text { Kesimp } \\
\text { ulan }\end{array}$ \\
\hline 1 & $\begin{array}{c}\text { Postes K. } \\
\text { Eksperim } \\
\text { en }\end{array}$ & 6,29 & \multirow{2}{*}{1,71} & 1,668 & $\begin{array}{c}\text { Terima } \\
\mathrm{H}_{\mathrm{a}}\end{array}$ \\
\cline { 1 - 3 } 2 & $\begin{array}{c}\text { Postes K. } \\
\text { Kontrol }\end{array}$ & 5,64 & 4 & & \\
\hline
\end{tabular}

Observasi yang dilakukan pada kegiatan pembelajaran oleh observer bersifat langsung dan dilakukan oleh peneliti serta dibantu oleh 2 orang rekan peneliti dan kriteria penilaiannya berdasarkan pedoman observasi aktivitas belajar siswa. Jenis aktivitas yang diamati selama kegiatan pembelajaran, yaitu : (1) kerja sama dengan kelompok, (2) keseriusan dalam belajaran, (3) tanggung jawab, (4) mengajukan pertanyaan, (5) menjawab pertanyaan. Aspek - aspek tersebut diberi skor 1 sampai 4 dengan pedoman pada lembar observasi aktivitas siswa.

Berdasarkan

hasil rekapitulasi maka aktivitas siswa pada pertemuan pertama dengan menerapkan model pembelajaran berbasis masalah diperoleh skor rata-rata $57,44 \%$ dalam kategori cukup aktif. Pada pertemuan kedua diperoleh peningkatan yang positif terhadap aktivitas siswa diperoleh skor rata-rata $72,32 \%$ dengan kategori cukup aktif. Pada pertemuan yang ketiga diperoleh peningkatan yang positif juga terhadap aktivitas siswa diperoleh skor rata-rata $78,64 \%$ dengan kategori cukup aktif, maka dapat disimpulkan bahwa model ini dapat meningkatkan aktivitas siswa. Jadi, penerapan model pembelajaran berbasis masalah di dalam kelas dapat meningkatkan aktivitas siswa.

\section{b. Pembahasan}

Pengaruh model pembelajaran berbasis masalah memberikan perbedaan terhadap hasil belajar dikarenakan model pembelajaran berbasis masalah dapat meningkatkan aktivitas, kemampuan berpikir kritis dan kreatif, serta kemampuan pemecahan masalah siswa. Model pembelajaran berdasarkan masalah merupakan suatu model pembelajaran yang didasarkan pada banyaknya permasalahan yang membutuhkan penyelidikan autentik yakni penyelidikan yang membutuhkan penyelesaian nyata dari permasalahan yang nyata. Pembelajaran berdasarkan masalah merupakan pendekatan yang efektif untuk pengajaran proses berpikir tingkat tinggi (Trianto, 2010:92). Pembelajaran ini membantu siswa untuk memproses informasi yang sudah jadi dalam benaknya dan menyusun pengetahuan mereka sendiri tentang dunia sosial dan sekitarnya. Pembelajaran ini cocok untuk mengembangkan pengetahuan dasar maupun kompleks.

Menurut Arends (Trianto, 2010:92), pembelajaran berdasarkan masalah merupakan suatu pendekatan pembelajaran di mana siswa mengerjakan permasalahan yang autentik dengan maksud untuk menyusun pengetahuan mereka sendiri, mengembangkan inkuiri dan ketrampilan berpikir tingkat lebih tinggi, mengembangkan kemandirian dan percaya diri. Model pembelajaran ini 
juga mengacu pada model pembelajaran yang lain, seperti "pembelajaran berdarkan proyek (project-based instruction)", "pembelajaran berdasarkan pengalaman instruction)", (experience-based belajar otentik (authentic learning) dan "pembelajaran bermakna (anchored instruction).

\section{Pembelajaran}

berbasis masalah melibatkan semua siswa aktif di kelas salam kerja sama dan mencari solusi dari permasalahan yang sedang dikaji melalui kegiatan tanya jawab. Masalah yang disajikan dibuktikan melalui kegiatan eksperimen yang menuntut setiap siswa dalam kelompoknya untuk ikut berpartisipasi. Masing - masing siswa menyampaikan pendapatnya mengenai solusi dari masalah yang disajikan kemudian berdiskusi untuk mencari solusi yang paling tepat. Kemudian masing-masing kelompok menyajikan hasil diskusinya di depan kelas. Keterlibatan aktif semua siswa selama proses pembelajaran akan mampu meningkatkan hasil belajar siswa terutama hasil belajar kognitif. Hal ini sejalan dengan penelitian Asistu (2013), yang memperoleh kesimpulan bahwa terdapat perbedaan yang signifikan secara simultan aktivitas dan prestasi belajar antara siswa yang belajar dengan penerapan model pembelajaran berbasis masalah dengan model pembelajaran langsung pada pembelajaran IPA pada siswa kelas VII MTs. Mu'allimat NW Pancor.

Model pembelajaran berbasis masalah juga dapat meningkatkan kemampuan berpikir kritis dan kreatif siswa. Prinsip pelaksanaan pembelajaran berbasis masalah, yaitu dalam proses belajar, siswa dituntut melakukan pemecahan masalah-masalah yang disajikan dengan cara menggali informasi sebanyak-banyaknya, dianalisis kemudian dicari solusi dari permasalahan yang ada. Melalui pembelajaran berbasis masalah dengan anggota kelompok yang heterogen memungkinkan siswa untuk saling bertukar pikiran, bekerjasama untuk memcahkan masalah yang pada akhirnya dapat meningkatkan kemampuan berpikir kritis. Selain itu, siswa juga dituntut untuk belajar secara kreatif terutama dalam menggali dan memecahkan permasalahan. Siswa diharapkan menjadi individu yang berwawasan luas serta mampu melihat hubungan pembelajaran dengan aspek-aspek yang ada di lingkungannya sehingga siswa tidak hanya mempelajari teori namun juga melihat fakta di lingkungan. Sehingga pembelajaran berbasis masalah mampu meningkatkan kemampuan siswa untuk berpikir kritis dan kreatif. Hal ini sejalan dengan penelitian Setyorini (2011) diperoleh bahwa model pembelajaran berbasis masalah dapat meningkatkan kemampuan kritis siswa. Selain itu, didukung juga oleh penelitian Liliawati (2010) yang memperoleh bahwa penerapan model pembelajaran berbasis masalah dapat meningkatkan berpikir kreatif siswa.

Dengan penerapan model pembelajaran berbasis masalah di dalam kelas juga dapat meningkatkan kemampuan pemecahan masalah adalah kemampuan individu dalam menggunakan proses berpikirnya 
untuk memecahkan permasalahan melalui pengumpulan fakta-fakta, analisis informasi, menyusun berbagai alternatif pemecahan dan memilih pemecahan yang paling efektif. Di dalam model pembelajaran berbasis masalah siswa melakukan serangkaian aktivitas pembelajaran yang menekankan pada proses pemecahan masalah yang dihadapi secara ilmiah. Selama proses pembelajaran dengan model pembelajaran berbasis masalah siswa tidak diharapkan hanya sekedar mendengarkan, mencatat, kemudian menghafal materi pembelajaran, akan tetapi dengan model pembelajaran berbasis masalah siswa aktif berfikir, berkomunikasi, mencari dan mengolah data, serta akhirnya menyimpulkan. Dengan pembelajaran yang sedemikian rupa mengarahkan siswa dituntut untuk mampu memberikan solusi pemecahan masalah yang sedang dikaji. Hal ini sejalan dengan penelitian yang dilakukan oleh Dewi (2012), diperoleh bahwa terdapat perbedaan kemampuan pemecahan masalah antara kelompok siswa yang belajar melalui model pembelajaran langsung.

\section{KESIMPULAN DAN SARAN}

\section{a. Kesimpulan}

Hasil belajar siswa pada materi pokok besaran fisika dan satuannya dengan menggunakan model pembelajaran masalah secara individu terdapat 15 orang siswa yang tuntas $(44 \%)$ dan secara kelas dinyatakan tidak tuntas. Hasil belajar siswa pada materi pokok besaran fisika dan satuannya dengan menggunakan model pembelajaran konvensional secara individu terdapat 11 orang siswa yang tuntas (31\%) dan secara kelas dinyatakan tidak tuntas. Berdasarkan hasil pengujian hipotesis dengan uji-t satu pihak diperoleh bahwa ada perbedaan akibat pengaruh model pembelajaran berbasis masalah terhadap hasil belajar siswa pada materi pokok besaran fisika dan satuannya di kelas X semester I SMA Katolik Budi Murni 3 Medan T.P. 2013/2014. Aktivitas belajar siswa pada materi pokok besaran pokok besaran fisika dan satuannya dengan menggunakan model pembelajaran berbasis masalah di kelas X SMA Katolik Budi Murni 3 Medan Semester Ganjil T.P. 2013/2014 termasuk kategori cukup baik.

\section{b.Saran}

Guru sebaiknya lebih jeli dalam memilih dan memilah masalah yang akan diberikan kepada siswa. Sebaiknya yang berhubungan dengan kehidupan mereka secara langsung. Ada kalanya siswa tidak tertarik pada masalah yang diajukan oleh guru, sehingga mereka cepat bosan dan jenuh selama pembelajaran berlangsung. Pada saat pembagian kelompok sebaiknya guru menuntun siswa untuk membentuk kelompok. Hal yang sering terjadi adalah para siswa justru menjadi ribut saat pembagian kelompok apabila pembagian kelompok diserahkan kepada siswa. Guru sebaiknya mempersiapkan alat dan bahan yang diperlukan saat melakukan eksperimen dari rumah karena bisa saja alat dan bahan yang diperlukan untuk melakukan eksperimen tidak tersedia di laboratorium. Guru sebaiknya memberikan motivasi 
terlebih dahulu kepada siswa yang akan mempresentasikan hasil karya mereka, karena sering terjadi siswa merasa malu-malu dan kurang percaya diri saat tampil di depan kelas.

\section{DAFTAR PUSTAKA}

Arends, Richard I., (2008). Belajar Untuk Mengajar,Pustaka Pelajar; Yogyakarta.

Asistu., (2013), Pengaruh Model Pembelajaran Berbasis Masalah Terhadap Hasil Belajar Siswa Pada Materi Energi di Kelas VIII Semester II SMP Swasta Madya Utama edan T.P 2008/209. Skripsi, FMIPA, UNIMED, Medan

Dewi., (2012), Pengaruh Model Pembelajaran Berbasis Masalah Terhadap Hasil Belajar Siswa Pada Materi Pokok Hukum Newton di Kelas VIII SMPN 6 Medan T.P 2009/2010. Skripsi, FMIPA, UNIMED, Medan

Kennedy., (2009), Pengaruh Model Pembelajaran Berbasis Masalah Terhadap Hasil Belajar Siswa Pada Materi Pokok Pemuaian di Kelas X Semester II SMAN 4 Kisaran T.P 2009/2010. Skripsi, FMIPA, UNIMED, Medan

Liliawati., (2010), Pengaruh Model Pembelajaran Berbasis Masalah Terhadap Hasil Belajar Siswa Pada Materi Pokok Kesetimbangan Benda Tegar di Kelas XI Man I Medan Semester II SMAN 4 Kisaran T.P 2011/2012. Skripsi, FMIPA, UNIMED, Medan
Setyorini.,(2011), Pengaruh Model Pembelajaran Berbasis Masalah Terhadap Hasil Belajar Siswa Pada Materi Pokok Momentum dan Impuls di Kelas XI Semester II SMAN 5 Medan T.P 2011/2012. Skripsi, FMIPA, UNIMED, Medan

Siagian, L., (2010), Pengaruh Model Pembelajaran Berbasis Masalah Terhadap Hasil Belajar Siswa Pada Materi Pokok Listrik Dinamis di Kelas X Semester II SMPN 2 Rantau Utara T.P 2009/2010. Skripsi, FMIPA, UNIMED, Medan.

Sudjana, N., (2005). Metode Statistika. Tarsio; Bandung.

Trianto, (2009) . Mendesain Model Pembelajaran Inovatif Progesif. Kencana; Jakarta. 